\title{
ANAEROBIC DIGESTION OF WHEAT STRAW AND MICOBIOLOGICAL ASSESMENT OF THE RESULTED DIGESTATE
}

\author{
Hristo Najdenski, Lyudmila Dimitrova, Veselin Akivanov, Venelin Hubenov, Snejanka Mihailova, \\ Petar Grozdanov, Mihail Iliev, Vesselin Kussovski, Lyudmila Kabaivanova, Ivan Simeonov
}

\begin{abstract}
A study on the anaerobic digestion of wheat straw in a pilot scale bioreactor with an organic load of 2, 5, 7, 10 and $20 \mathrm{~g} / \mathrm{l}$ and a process duration of 18 to 80 days was performed. The pilot bioreactor used has a computerized system for control and monitoring of various operational parameters - temperature, $\mathrm{pH}$, biogas composition, etc. Total solids, total organics and volatile fatty acids were measured by standard methods and gas chromatography. Daily biogas yield and its main components $\left(\mathrm{CH}_{4}, \mathrm{CO}_{2}, \mathrm{H}_{2} \mathrm{~S}\right)$ were analysed too. During the anaerobic digestion, different species of microorganisms have been isolated from the genera Bacillus, Pseudomonas, Enterococcus and Aeromonas, as well as the species Terribacillus halophilus. With a known pathogenic potential are described Pseudomonas sp., Enterococcus sp. and Aeromonas sp. Studies on the antimicrobial resistance of all isolated strains show resistance to ampicillin, amoxicillin, bacitracin, ceftriaxone, gentamicin and vancomycin. The cellulose degrading activity of some of the bacterial isolates, their pathogenic potential and antimicrobial resistance are discussed in detail in the light of the data on the mechanisms of proven resistance.
\end{abstract}

Keywords: anaerobic digestion, wheat straw, batch processes, organic load, computer controlled pilot-scale biogas plant, mesophilic bacterial consortia, digestate.

\section{INTRODUCTION}

Anaerobic digestion (AD) of organic wastes is a very attractive biotechnology during the last years mainly in the field of the renewable energy sources and biofuels. However, this biotechnology could be successfully applied for depollution of highly polluted with organics waste waters and municipal wastes [1-3].

The biogas is an additional energy source which can replace fossil fuel sources. It therefore has a direct positive effect on the greenhouse gas reduction.

The recent article describes briefly the new pilotscale biogas plant with computerized monitoring and control system of the Stephan Angeloff Institute of Microbiology - Bulgarian Academy of Sciences (SAIM-BAS). This biogas plant will be very useful for development of new optimised technologies for anaerobic digestion and co-digestion of different organic wastes and for multidisciplinary studies of this kind of processes (microbiological and biochemical studies, mathematical modelling with parameter and states estimation, sophisticated control algorithms development, new software sensors development, etc.).

Some results from AD of three types of lignocellulose waste (cornstalks, wheat straw and barley straw) with the pilot-scale biogas plant were presented in our previous study [4]. Moreover, we obtained very promising results with a maximum of the biogas flow rate for an optimal ratio cattle dung/wheat straw [5].

Digestate can be defined as liquid effluent from anaerobic digestion of animal and plant waste [6]. It can be used as soil fertilizer due to its content of mineral elements (nitrogen, phosphorus, potassium), which are easily available for plants [7]. The agrochemical properties of the digestate depend on the raw material, methods of pre-treatment, fermentation temperature, speed of the process, storage of the digestate, etc. The nature of the raw materials used is a risk factor for infections due to the possible presence of pathogenic microorganisms [8]. When fertilizing, both pathogenic microorganisms and growth-promoting bacteria enter into the soil and could be applied for biocontrol of plant diseases. In agricultural production, chemicals are often used as protective agents, but their increasing application lead to development of pathogen resistance. Nowadays, many producers are focused to application of biological preparations containing some bacteria or their metabolic products. The beneficial bacteria include representatives of the genus Bacillus and the species T. halophilus, and the potentially pathogenic ones - Pseudomonas sp., Enterococcus sp. and Aeromonas sp. as well.

It is well known that the liquid effluent of the $\mathrm{AD}$ (known as digestate) may be used as a natural fertilizer for biological agricultural production [1-3]. Our previous experiments showed that even in the case of $\mathrm{AD}$ of lignocellulose waste the quality of the digestate as a natural fertilizer is quite well [9]. However the possible availability of pathogens [10] may pose some problems for its use as a natural fertilizer for growing plants for human and animal nutrition. Some studies in this area are needed. Additionally, the presence of saprophytic, opportunistic and pathogenic microorganisms, carriers of antimicrobial resistance are an additional risk factor for the spread of this important phenomenon in nature and for human and animal health in the context of the concept "One Health". 
The aim of this paper is to study the influence of the organic load on AD of untreated wheat straw in a pilot biogas plant and the possibility for decontamination of antibiotic resistance in the digestate obtained.

\section{MATERIALS AND METHODS}

\section{Pilot-scale biogas plant}

Anaerobic digestion $(\mathrm{AD})$ was realized in a pilot scale biogas plant with automatic control system at mesophilic temperature $-37^{\circ} \mathrm{C}$ and bioreactor working volume of $80 \mathrm{dm}^{3}$. The cultivation was in a batch operation. The calculated quantity of wheat straw diluted in water for the appropriate organic loading was added into the bioreactor after taking out the same quantity of liquid from the bioreactor at the beginning of the process.
All experiments were conducted at least in triplicate.

\section{Organic loads assessment}

Total solids (TS) and volatile solids (VS) or total organics (TO) were measured according to standard methods [20]. The concentration of volatile fatty acids (VFAs) was analyzed using Thermo Scientific, Focus GC gas chromatograph equipped with TG-WAXMS A column (L: $30 \mathrm{~m}$, I.D.: $0.25 \mathrm{~mm}$, Film: $0.25 \mu \mathrm{m})$, Split/Splitless injector and FID flame ionization detector. Daily biogas yield was analyzed using graduated gasholder working on a water displacement method. To follow the biogas composition, the main components of biogas mixture $-\mathrm{CH}_{4}, \mathrm{CO}_{2}$ and $\mathrm{H}_{2} \mathrm{~S}$ were analyzed using Dräger $\mathrm{X}$-am7000, equipped with infrared sensors (Fig. 1).

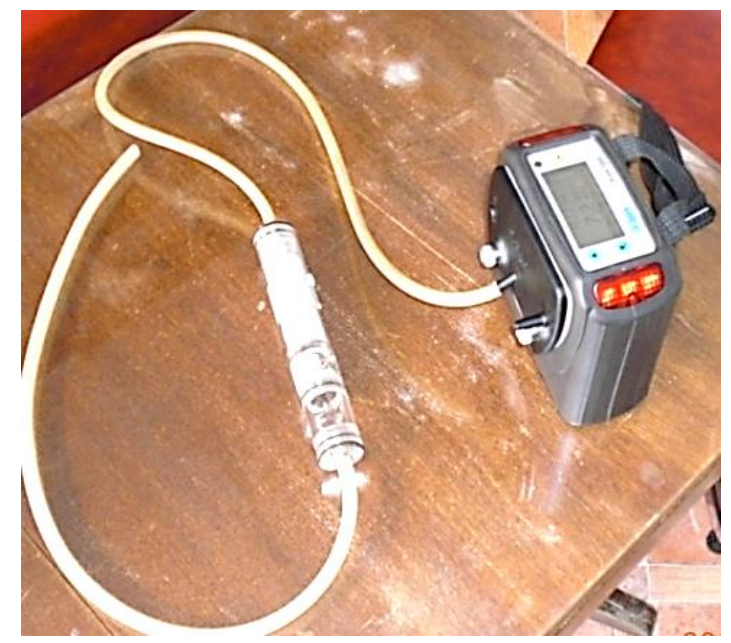

Fig. 1. Dräger X-am7000 device for measurement of $\mathrm{CH}_{4}, \mathrm{CO}_{2}$ and $\mathrm{H}_{2} \mathrm{~S}$ in the obtained biogas

In our previous studies $[11,12]$ the pilot biogas plant of SAIM-BAS was presented in details. The total volume of the bioreactor (BR) is $100 \mathrm{dm}^{3}$ and the commonly used working volume $-80 \mathrm{dm}^{3}$.

\section{Calculations}

Based on the experimental data obtained, some basic parameters were calculated using the following formulas:

$$
\begin{aligned}
& \mathrm{DBD}_{\mathrm{TS}}=\left(\mathrm{TS}_{\text {influent }}-\mathrm{TS}_{\text {effluent }}\right) / \mathrm{TS}_{\text {influent }}= \\
& \Delta \mathrm{TS} / \mathrm{TS}_{\text {influent }} .100[\%] \\
& \mathrm{DBD}_{\mathrm{TO}}=\left(\mathrm{TO}_{\text {influent }}-\mathrm{TO}_{\text {effluent }}\right) / \mathrm{TO}_{\text {influent }}= \\
& \Delta \mathrm{TO} / \mathrm{TO}_{\text {influent }} .100[\%] \\
& \mathrm{Q}_{\text {specific }} \quad \text { biogas }=\mathrm{Q}_{\text {biogas }} / \Delta \mathrm{TO} \quad\left[\mathrm{dm}^{3} \text { biogas } / \mathrm{g}\right. \\
& \text { biodegraded organics] } \\
& \mathrm{Q}_{\text {specific methane }}=\mathrm{Q}_{\text {methane }} / \Delta \mathrm{TO} \quad\left[\mathrm{dm}^{3} \text { methane } / \mathrm{g}\right.
\end{aligned}
$$

biodegraded organics],

where:
DBD [\%] - degree of biodegradation

TS $[\mathrm{g} / \mathrm{l}]$ - total solids

TOM (TO) $[\mathrm{g} / \mathrm{l}]$ - total organic matter (total organics)

$\mathrm{Q}_{\text {specific biogas }}\left(\mathrm{dm}^{3} / \mathrm{g}\right.$ TOM $)$ - the biogas yield from $1 \mathrm{~g}$ biodegraded TOM

$Q_{\text {specific methane }}\left(\mathrm{dm}^{3} / \mathrm{g}\right.$ TOM $)$ - the methane yield from $1 \mathrm{~g}$ biodegraded TOM

$\mathrm{Q}=\mathrm{Q}_{\text {cumulative }}\left[\mathrm{dm}^{3}\right]-$ cumulative biogas production from the process

$\mathrm{Q}_{\text {methane }}=\mathrm{Q}$ cumulative methane $\left[\mathrm{dm}^{3}\right]$ - cumulative methane production from the process

\section{Pilot biogas plant}

The block-scheme of the biogas plant of SAIMBAS with a system for monitoring and control is shown on Fig. 2 and a general view of the pilot-scale biogas plant - on Fig. 3 . 


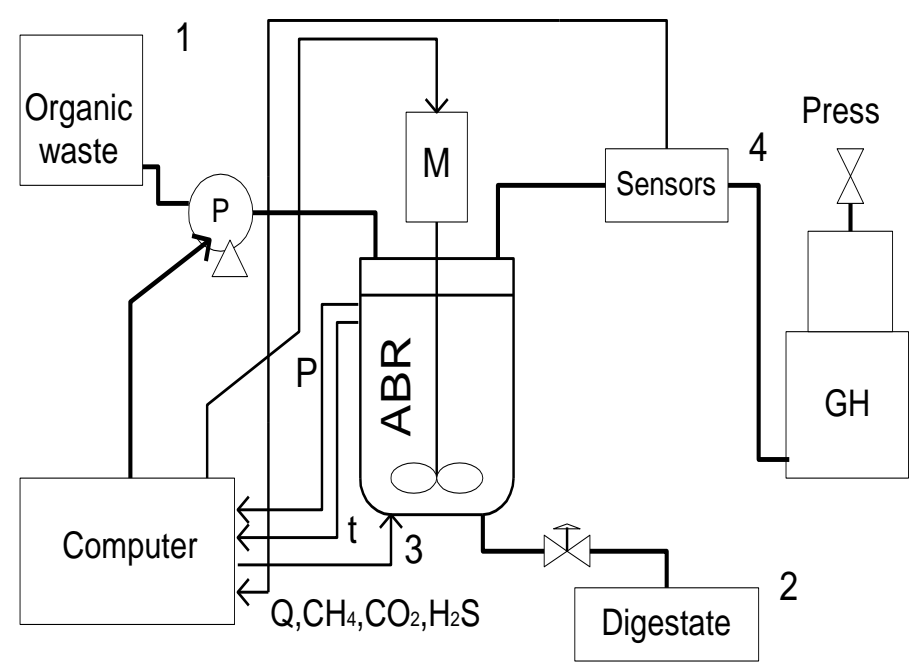

Fig. 2. Block-scheme of the pilot-scale biogas plant with a system for monitoring and control [13]

\section{Control system}

The control system is built on two levels - a computer and an industrial controller, which communicate through an appropriate communication protocol - the Internet. The topology of such a system, consisting of a personal computer and a controller is shown [13]. The controller in real time performs the following functions:

- measuring the parameters of the technological process;

- calculation of control system parameters;
- output of control signals to the process;

- communication with the upper technological level - personal computer.

The "Computer System-PLC" is described in details [13]. The measured parameters are monitored every two hours, and their graphs are displayed for a period of 30 days (360 measured values) (Fig. 4). The ordinate axis markings contain the date and time of measurement (for flow only the date, as the measured flow for 24 hours is displayed). The measured values for the period shown in the chart are displayed on the abscissa.

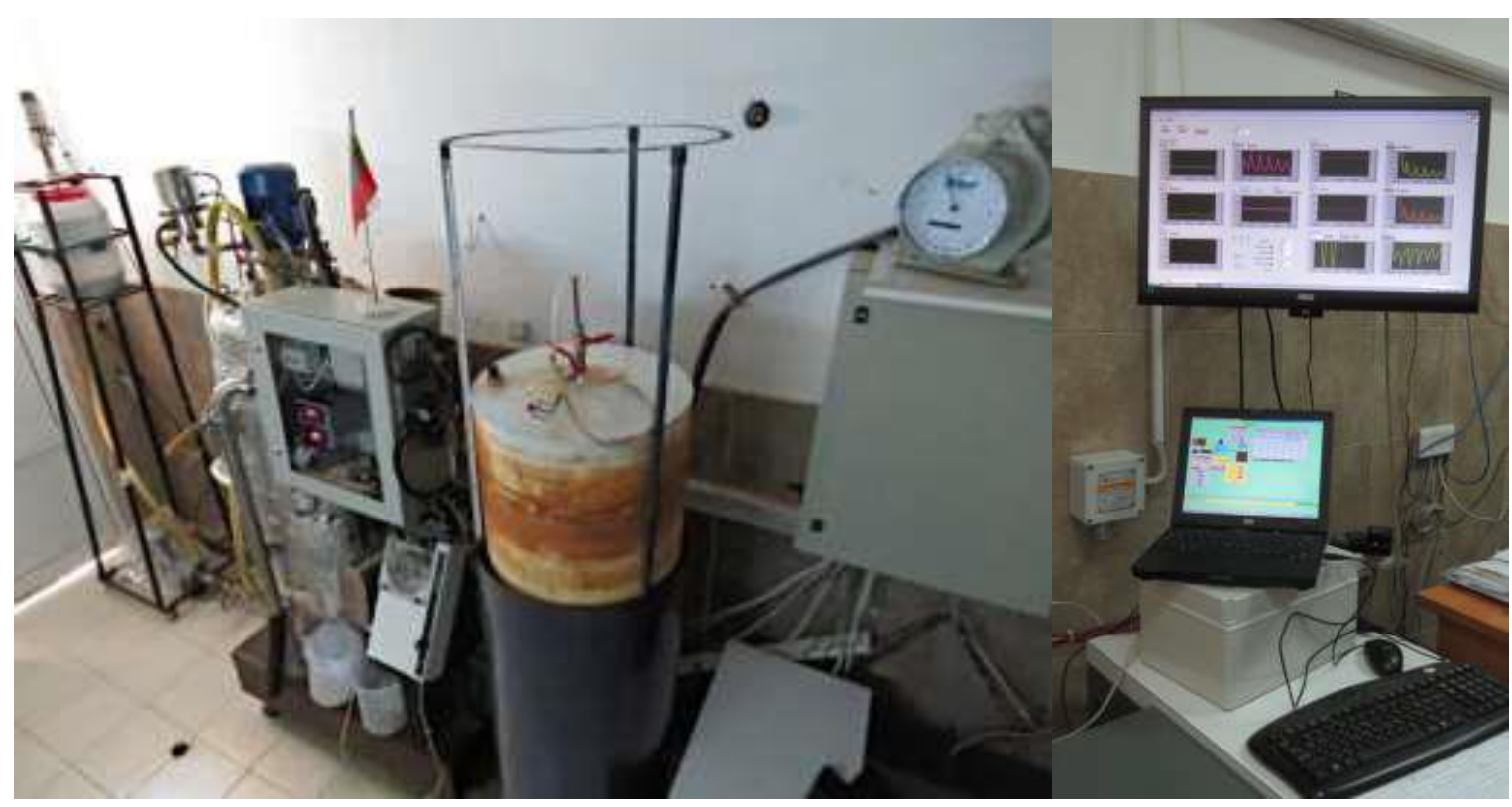

Fig. 3. General view of the pilot-scale biogas plant 


\section{Isolation of bacteria, culture media and growth conditions}

The sample from digestate was inoculated directly on Nutrient agar (SM001, HiMedia, India), MacConkey agar (M082A, HiMedia, India), HiCrome ${ }^{\mathrm{TM}}$ Chrome E. coli agar (C-4221, Sigma-Aldrich, USA), CHROMagar Orientation (RT410, CHROMagar, France), Chapman Stone agar (M215, HiMedia, India) and SalmonellaShigella (SS) agar (0074-01, Difco, USA) and cultured overnight at $37^{\circ} \mathrm{C}$. The isolated colonies were enriched in Brain Heart Infusion broth (CM225, Oxoid, England) and/or with 1,8\% agar, and subcultured at 37 ${ }^{\circ} \mathrm{C}$. Different selected colonies were isolated and microbial morphology was examined by light microscopy. The cultures were stored at $4{ }^{\circ} \mathrm{C}$ and were periodically re-stocked on solid and liquid media. Stocks with $25 \%$ glycerol were created for long-term storage at $-20{ }^{\circ} \mathrm{C}$. All strains were deposited in the SAM-BAS.

\section{Microbial identification}

Genomic DNA was extracted from $500 \mu 1$ overnight bacterial culture, using GenElute Bacterial Genomic DNA Kit (cat. № NA2100, Sigma-Aldrich, USA). The DNA concentration were measured using a QB 3000 spectrophotometer. Polymerase chain reactions (PCR) were performed with universal bacterial primers specific for 16S rDNA (27F: 5'-AGA GTT TGA TCM TGG CTC AG-3' and 1492R-2: 5'GGY TAC CTT GTT ACG ACT T-3') (Lane et al., 1991). Identification was performed with a sequence analysis performed at MACROGEN (The Netherlands).

\section{Antimicrobial resistance (AMR)}

The sensitivity of the isolated bacterial strains was determined, according to European Committee on Antimicrobial Susceptibility Testing (EUCAST) guidelines [14], using antibiotic disks (BB-NCIPD Ltd., Sofia, Bulgaria) by the disk-diffusion method. For this purpose, $100 \mu \mathrm{l}$ from bacterial suspension $\left(10^{5} \mathrm{CFU} / \mathrm{ml}\right)$ were inoculated into petri plates $(90$ $\mathrm{mm}$ ) loaded with $20 \mathrm{ml}$ Brain Heart Infusion agar.

\section{RESULTS AND DISCUSSION}

A large number of experimental studies in batch mode of operation have been carried out with untreated wheat straw in two stages:

1. Co-digestion of cattle dung and wheat straw for adaptation of the bacterial community;

2. AD of untreated wheat straw with different organic loads (from 2 to $41 \mathrm{~g} / \mathrm{l}$ ).

\subsection{Co-digestion of cattle dung and wheat straw}

In our previous studies we obtained very interesting results with a maximum of the biogas flow rate for an optimal ratio cattle dung/wheat straw [5]. However, in this study the co-digestion of cattle dung and wheat straw is the first stage for adaptation of the bacterial community to work only with wheat straw. This adaptation was obtained only with two experiments:

- First experiment was carried out with organic load of 18,093 g/l (10\% of wheat straw) - cumulative biogas production of $18,78 \mathrm{dm}^{3}$ for 14 days was gained and at the last day of the experiment $(\mathrm{pH}=7,1)-\mathrm{CH}_{4}=$ $51 \%, \mathrm{CO}_{2}=39 \%$, and $\mathrm{H}_{2} \mathrm{~S} \geq 1000 \mathrm{ppm}$.

- The second experiment was performed with organic load of 18,13 g/l (20\% of wheat straw). The cumulative biogas production get to $49,46 \mathrm{dm}^{3}$ for 23 days and within the last day of the experiment ( $\mathrm{pH}=7,1)-\mathrm{CH}_{4}=55 \%, \mathrm{CO}_{2}=41 \%$, and $\mathrm{H}_{2} \mathrm{~S} \geq 1000$ ppm.

All obtained parameters were usual excepting the high level of $\mathrm{H}_{2} \mathrm{~S}$.

\subsection{AD of untreated wheat straw}

In our previous studies we have experimented $\mathrm{AD}$ of different types of lignocellulose waste (cornstalks, wheat straw and barley straw) with and without pretreatment $[4,13,15]$. The results show that the application of pretreatment of plant waste leads to a significant increase in the specific yield of both biogas and methane. However, pretreatment needs of time and additional investments. That is why we experimented $\mathrm{AD}$ of untreated wheat straw with different organic loads.

In each experiment, the TS and TO of straw were measured, which were about the following: TS $=93.39 \%$; and $\mathrm{TO}=95.18 \%$.

The obtained experimental results from AD of wheat straw with different organic load are summarized in Table 1.

Daily evolution of the biogas flow rates for organic loads (TO) of 2, 5, 7, 10 and $20 \mathrm{~g} / \mathrm{l}$ are presented on Fig. 5 and for process with inhibition (organic load of $\mathrm{TO}=38,3 \mathrm{~g} / \mathrm{l}$ ) - on Fig. 6 . 
Table 1. Final results with six batch processes for different intervals and organic loads

\begin{tabular}{|c|c|c|c|c|c|c|}
\hline $\begin{array}{l}\text { Experiment duration } \\
\text { [day] }\end{array}$ & $\begin{array}{c}\text { Process } \\
1\end{array}$ & $\begin{array}{c}\text { Process } \\
2\end{array}$ & $\begin{array}{c}\text { Process } \\
3\end{array}$ & $\begin{array}{c}\text { Process } \\
4\end{array}$ & \begin{tabular}{|c|} 
Process \\
5 \\
\end{tabular} & $\begin{array}{c}\text { Process } \\
6\end{array}$ \\
\hline Parameters & 18 & 29 & 28 & 26 & 30 & 80 \\
\hline Organic Load (TO) $[\mathrm{g} / \mathrm{l}]$ & 2,13 & 4,89 & 7,11 & 9,44 & 19,37 & 38,3 \\
\hline $\mathrm{Q}_{\text {cumulative }}\left[\mathrm{dm}^{3}\right]$ & 74,69 & 160,54 & 345,71 & 405,18 & 687,16 & 1695,99 \\
\hline $\mathrm{CH}_{4}[\%]$ & 51 & 53 & 52 & 55 & 56 & 60 \\
\hline $\mathrm{CO}_{2}[\%]$ & 45 & 45 & 46 & 45 & 41 & 40 \\
\hline $\mathrm{H}_{2} \mathrm{~S}[\mathrm{ppm}]$ & 860 & 570 & 470 & 340 & 0 & 0 \\
\hline $\mathrm{DBD}_{\mathrm{TS}}[\%]$ & - & - & 25,12 & - & 9,7 & - \\
\hline $\mathrm{DBD}_{\mathrm{TO}}[\%]$ & - & - & 34,57 & - & 34,9 & - \\
\hline $\begin{array}{c}\mathrm{Q}_{\text {specific biogas }} \\
{\left[\mathrm{dm}^{3} / \mathrm{g} \text { biodegraded organics }\right]}\end{array}$ & - & - & 0,354 & - & 0,6045 & - \\
\hline $\begin{array}{c}Q_{\text {specific methane }} \\
{\left[\mathrm{dm}^{3} / \mathrm{g} \text { biodegraded organics }\right]}\end{array}$ & - & - & 0,148 & - & 0,3385 & - \\
\hline
\end{tabular}

From the results shown in Table 1 and on Fig. 2 it can be seen that under organic loading in the range of $2-20 \mathrm{~g} / \mathrm{l}$ the processes proceed normally with continuously increasing yields of biogas and methane (the dependence is closer to linear) and decreasing content of $\mathrm{H}_{2} \mathrm{~S}$. Their duration is $26-30$ days. The specific yields of biogas and methane (from $1 \mathrm{~g}$ of biodegraded organics) are quite good and also increase, although the dependence is not linear. The DBD rate is about $35 \%$, which is the approximate content of cellulose in the straw.

\section{AD of wheat straw with different organic loads [g/l]}

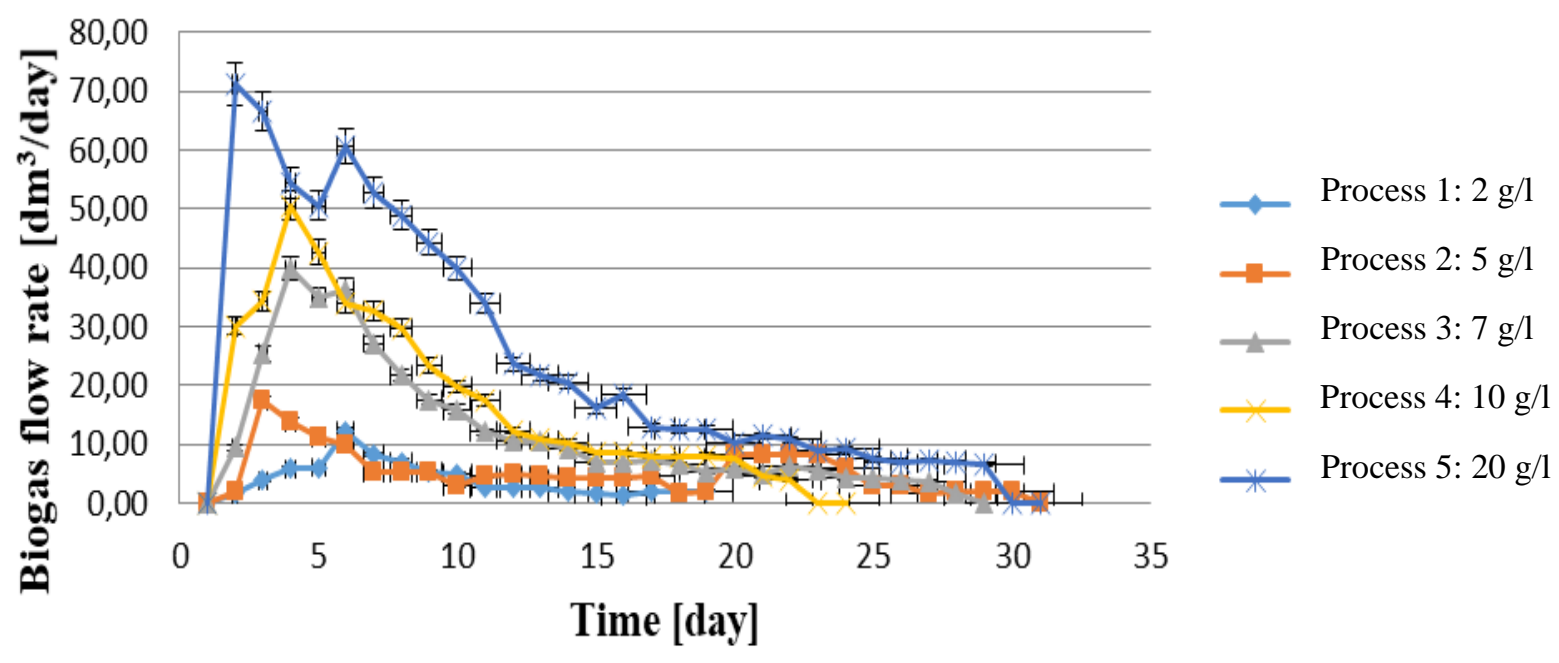

Fig. 5. Daily evolution of the biogas flow rates for different intervals and organic loads $(2,5,7,10$ and $20 \mathrm{~g} / \mathrm{l})$ 


\section{AD of wheat straw with overloading (41 g/l organic load) and inhibition}

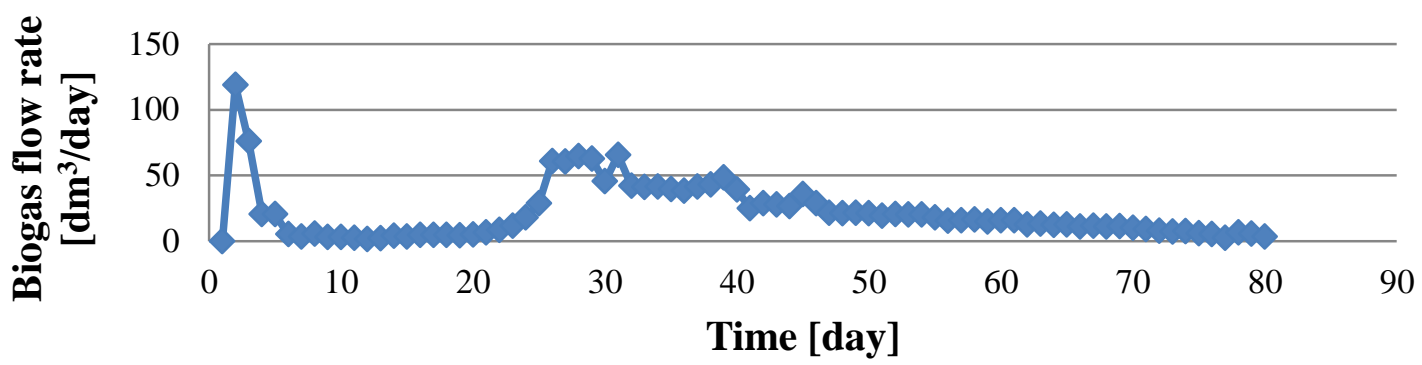

Fig. 6. Daily evolution of the biogas flow rates for organic loads of $41 \mathrm{~g} / \mathrm{l}$ (process 6 with inhibition)

The results in Table 1 and on Fig. 6 show that an organic loading of $38.3 \mathrm{~g} / \mathrm{l}$ results in overloading (substrate inhibition), whereby on the $12^{\text {th }}$ day the $\mathrm{pH}$ drops to 6.2 and the total concentration of VFA reaches $3.45 \mathrm{~g} / \mathrm{l}$. After gentle repeated $\mathrm{pH}$ adjustments with sodium hydroxide up to 6.8 , by the $25^{\text {th }}$ day, the process was restored and intensive yield of biogas with a high content $(60 \%)$ of methane started. Total biogas production exceeds more than twice the case with organic load of $19.37 \mathrm{~g} / \mathrm{l}$, but also at a significantly longer process time.

\section{IDENTIFICATION OF BACTERIA}

At different intervals of the above presented AD processes, samples of the effluent digestate were taken sterile for microbiological examination in order to determine the species composition of the bacterial consortia, incl. enteropathogenic species.

A total of 16 Gram-positive and Gram-negative bacterial strains were isolated from the methanogenic bioreactor digestate. Eight single colonies were isolated from MacConkey agar, from CHROMagar Orientation - 1 colony, from Nutrient agar -3 colonies, from HiCrome ${ }^{\mathrm{TM}}$ Chrome E. coli agar - 2 colonies, from SS agar - 1 colony and from Chapman Stone agar -1 single colony. The results are shown on Table 2. By using 16S rDNA PCR identification representatives of the genera Pseudomonas, Bacillus, Enterococcus and Aeromonas, as well as Terribacillus halophilus were proved. The main bacterial species isolated from the digestate after culturing on the specific nutrient media are presented in Table 2 .

Table 2. Isolated and identified bacterial species from digestate

\begin{tabular}{|c|c|c|c|c|}
\hline № & Species & Bases & Identity & Genes \\
\hline 1 & Pseudomonas protegens ${ }^{l}$ & 1229 & $99 \%$ & R-54758 16S \\
\hline 2 & Pseudomonas sp. ${ }^{l}$ & 1307 & $97 \%$ & PS1C1 16S \\
\hline 3 & Enterococcus sp. ${ }^{l}$ & 1525 & $97 \%$ & RCB276 16S \\
\hline 4 & Pseudomonas sp. ${ }^{l}$ & 1522 & $97 \%$ & $\mathrm{~J} 4.2 \mathrm{~B} 416 \mathrm{~S}$ \\
\hline 5 & Enterococcus sp. ${ }^{l}$ & 1425 & $98 \%$ & RCB276 16S \\
\hline 6 & Pseudomonas xanthomarina ${ }^{l}$ & 1062 & $98 \%$ & SBANSCu22 16S \\
\hline 7 & Bacillus methylotrophicus ${ }^{l}$ & 1387 & $96 \%$ & SCDB1474 16S \\
\hline 8 & Enterococcus sanguinicola ${ }^{l}$ & 1300 & $98 \%$ & BAA-781 16S \\
\hline 9 & Aeromonas sp. ${ }^{2}$ & 1365 & $97 \%$ & $\mathrm{~J} 1.3 \mathrm{E} 216 \mathrm{~S}$ \\
\hline 10 & Aeromonas sp. ${ }^{2}$ & 1271 & $96 \%$ & J1.3E2 16S \\
\hline 11 & Bacillus amyloliquefaciens ${ }^{3}$ & 1313 & $97 \%$ & EA1-10 16S \\
\hline 12 & Bacillus subtilis $^{4}$ & 1356 & $90 \%$ & LM $6116 \mathrm{~S}$ \\
\hline
\end{tabular}




\begin{tabular}{|r|l|r|r|l|}
\hline 13 & Pseudomonas sp. $^{4}$ & 1421 & $96 \%$ & J4.2B4 16S \\
\hline 14 & Bacillus flexus $^{4}$ & 1306 & $98 \%$ & NB4-9 16S \\
\hline 15 & Aeromonas sp. $^{5}$ & 1425 & $98 \%$ & J1.3E2 16S \\
\hline 16 & Terribacillus halophilus $^{6}$ & 895 & $98 \%$ & AK39315 16S \\
\hline
\end{tabular}

Legend: ${ }^{1}$ - from MacConkey agar; ${ }^{2}-$ HiCrome $^{\mathrm{TM}}$ Chrome E. coli agar; ${ }^{3}$ - from CHROMagar Orientation; ${ }^{4}$ - from Nutrient agar; ${ }^{5}$ - from SS agar; and ${ }^{6}$ - from Chapman Stone agar.

In additional study, we investigated the antimicrobial resistance of the isolated 8 strains to a total 10 antibiotics, divided into 7 different groups: penicillins (ampicillin (AMP, $10 \mu \mathrm{g}$ ) and amoxicillin (AMX, $25 \mu \mathrm{g}$ ), cephalosporins (ceftriaxone (CTR, $30 \mu \mathrm{g}$ ), fluoroquinolones (levofloxacin (LE, $5 \mu \mathrm{g}$ ) and ciprofloxacin (CIP $5 \mu \mu \mathrm{g})$ ), aminoglicosides (gentamicin - GEN, $10 \mu \mathrm{g}$ ) and tobramycin (TOB, $10 \mu \mathrm{g})$ ), tetracyclines (doxycycline - DO, $30 \mu \mathrm{g}$ ), polypeptides (bacitracin - B, $10 \mathrm{IU}$ ) and glycopeptides (vancomycin - VA, $30 \mu \mathrm{g}$ )) on Brain Heart Infusion agar. According to clinical breakpoints of EUCAST, the bacterial species $P$. protegens and $P$. xanthomarina were resistant $(\mathrm{R})$ to ampicillin, amoxicillin, bacitracin and vancomycin. They were sensitive (S) to gentamicin and doxycycline. In addition, $P$. xanthomarina was sensitive to ceftriaxone. $P$. protegens showed intermediate (I) sensitively to ceftriaxon, levofloxacin and ciprofloxacin, and $P$. xanthomarina - only to levofloxacin. E. sanguinicola was resistant to ampicillin, amoxicillin, gentamicin and bacitracin, sensitive to ceftriaxon, levofloxacin, ciprofloxacin, tobramycin, doxycycline and vancomycin. No specific criteria in requirements of EUCAST and Clinical and Laboratory Standards Institute (CLSI) were found about the susceptibility of Bacillus sp. to antibiotics (Table 3).

Table 3. Antibioticogram of isolated bacteria from digestate

\begin{tabular}{|c|c|c|c|c|c|c|c|c|c|c|c|}
\hline № & Species & $\mathbf{A M P}$ & B & AMX & CTR & LE & CIP & GEN & TOB & DO & VA \\
\hline 1 & Pseudomonas protegens & $\mathbf{R}$ & $\mathbf{R}$ & $\mathbf{R}$ & $\mathbf{R}$ & $S$ & $S$ & $S$ & $S$ & $\mathrm{~S}$ & $\mathbf{R}$ \\
\hline 2 & Pseudomonas sp. & $\mathbf{R}$ & $\mathbf{R}$ & $\mathbf{R}$ & $\mathbf{R}$ & $\mathrm{S}$ & $\mathrm{S}$ & $\mathrm{S}$ & $\mathrm{S}$ & $\mathrm{S}$ & $\mathbf{R}$ \\
\hline 3 & Enterococcus sp. & $\mathbf{R}$ & $\mathbf{R}$ & $\mathbf{R}$ & $\mathrm{S}$ & $S$ & $S$ & $S$ & $S$ & $\mathrm{~S}$ & $\mathbf{R}$ \\
\hline 4 & Pseudomonas sp. & $\mathbf{R}$ & $\mathbf{R}$ & $\mathbf{R}$ & $S$ & $S$ & $S$ & $S$ & $S$ & $\mathrm{~S}$ & $\mathbf{R}$ \\
\hline 5 & Enterococcus sp. & $\mathbf{R}$ & $\mathbf{R}$ & $\mathbf{R}$ & $S$ & $S$ & $\mathbf{I}$ & $\mathbf{R}$ & $S$ & $\mathrm{~S}$ & $\mathrm{~S}$ \\
\hline 6 & $\begin{array}{l}\text { Pseudomonas } \\
\text { xanthomarina }\end{array}$ & $\mathbf{R}$ & $\mathbf{R}$ & $\mathbf{R}$ & $S$ & $S$ & S & $S$ & $\mathrm{~S}$ & $\mathrm{~S}$ & $\mathbf{R}$ \\
\hline 7 & $\begin{array}{c}\text { Bacillus } \\
\text { methylotrophicus }\end{array}$ & $\mathbf{R}$ & $\mathbf{R}$ & $\mathrm{S}$ & $\mathrm{S}$ & $\mathrm{S}$ & S & S & S & $\mathrm{S}$ & $\mathrm{S}$ \\
\hline 8 & $\begin{array}{l}\text { Enterococcus } \\
\text { sanguinicola }\end{array}$ & $\mathbf{R}$ & $\mathbf{R}$ & $\mathbf{R}$ & $\mathrm{S}$ & $\mathrm{S}$ & S & $\mathbf{R}$ & $\mathrm{S}$ & $\mathrm{S}$ & $\mathrm{S}$ \\
\hline 9 & Aeromonas sp. & $\mathbf{R}$ & $\mathbf{R}$ & $\mathbf{R}$ & $\mathrm{S}$ & $\mathrm{S}$ & $\mathrm{S}$ & $S$ & $S$ & $\mathrm{~S}$ & $\mathbf{R}$ \\
\hline 10 & Aeromonas sp. & $\mathbf{R}$ & $\mathbf{R}$ & $\mathbf{R}$ & $\mathrm{S}$ & $\mathrm{S}$ & $\mathrm{S}$ & $\mathbf{R}$ & $S$ & $\mathrm{~S}$ & $\mathbf{R}$ \\
\hline 11 & $\begin{array}{c}\text { Bacillus } \\
\text { amyloliquefaciens }\end{array}$ & $\mathbf{R}$ & $\mathbf{R}$ & $\mathbf{R}$ & $\mathrm{S}$ & $\mathrm{S}$ & $\mathrm{S}$ & $S$ & $\mathrm{~S}$ & $\mathrm{~S}$ & $\mathbf{R}$ \\
\hline 12 & Bacillus subtilis & $\mathbf{R}$ & $\mathbf{R}$ & $\mathrm{S}$ & $S$ & $S$ & $S$ & $S$ & $S$ & $S$ & $S$ \\
\hline 13 & Pseudomonas sp. & $\mathbf{R}$ & $\mathbf{R}$ & $\mathbf{R}$ & $S$ & $S$ & $S$ & $S$ & $S$ & $S$ & $\mathbf{R}$ \\
\hline 14 & Bacillus flexus & $\mathbf{R}$ & $\mathbf{R}$ & $\mathbf{R}$ & $\mathbf{R}$ & $S$ & $S$ & $S$ & $S$ & $S$ & $\mathbf{R}$ \\
\hline 15 & Aeromonas sp. & $\mathbf{R}$ & $\mathbf{R}$ & $\mathbf{R}$ & $\mathrm{S}$ & $S$ & $S$ & $\mathrm{~S}$ & $S$ & $S$ & $S$ \\
\hline 16 & Terribacillus halophilus & $\mathbf{R}$ & $\mathbf{R}$ & $\mathbf{R}$ & $\mathrm{S}$ & $\mathrm{S}$ & $\mathrm{S}$ & $\mathrm{S}$ & $\mathrm{S}$ & $\mathrm{S}$ & $\mathbf{R}$ \\
\hline
\end{tabular}

Legend: R - resistant, $\mathrm{S}$ - sensitive, I - intermediate resistance 
Bacillus sp. are spore-forming bacteria and are found everywhere in the environment [16], including in foods of plant origin, but often isolated from meat and dairy products [17]. Representatives of this genus produce a variety of extracellular products, including antimicrobials, enzymes, pigments and toxins [18]. Phospholipase $\mathrm{C}$ plays a minor role in eye infections by destroying phospholipids on the membranes of the host cell exposed to other toxins [19]. B. subtilis suppresses fungal pathogens (antagonists) and/or causes protective reactions in plant tissues [20]. It synthesizes several types of extracellular enzymes, such as $\beta$-1,3-glucanase [21], cyclic lipopeptide antibiotics [22] and volatile organic compounds [23]. $B$. methylotrophicus sp. nov. is a methanol utilizing, plant-growth-promoting bacterium that produce 1aminocyclopropane-1-carboxylate deaminase (ACC deaminase) [24]. B. amyloliquefaciens is one of the most widely used species for the bulk production of $\alpha$-amylase [25], proteolytic enzymes and subtilin, an antimicrobial peptide active against foodborne pathogen Listeria monocytogenes [26]. It was demonstrated that $B$. amyloliquefaciens contains genes for and produces antifungal lipopeptides [27]. Some studies showed the potential of bacteria to enhanced the immunity to the Newcastle virus [28] and body mass of birds [29]. B. flexus contains extracellular alkalihalotolerant cellulase and have potential to degrade cellulose [30]. B. flexus S-27 possess extracellular synthesis of anisotropic silver nanoparticles and exhibited an antibacterial activity against clinically isolated multi-drug resistant bacterial pathogens, such as E. coli, B. subtilis, S. pyogenes and P. aeruginosa [31].

T. halophilus utilizes glycerol, L-arabinose, glucose, fructose, cellobiose, etc [32]. This species containes extracellular antifungal enzymes and intracellular proteins inhibiting spore germination and mycelial growth of fungus [33].

The genus Enterococcus is common in the microbiota of humans and animals, as well as in food and environment and is frequently associated with important antimicrobial resistance (AMR) markers, such as the dissemination of AMR genes and can cause invasive infections in humans. $E$. sanguinicola has previously been isolated from human blood [34]. One of the E. sanguinicola isolates was vancomycin resistant, due to presence of the vanA gene, which is often associated with $E$. faecalis and E. faecium, which belong to the same phenotypic group of enterococcal species [35]. Both species demonstrate resistance to important antibiotics, such as cephalosporins, aminoglycosides, clindamycin and trimethoprim-sulfamethoxazole, either through mutation or by horizontal transfer of genetic resistance determinants [36].

The representatives from the genus Pseudomonas causes infections mainly in hospitalized, immunocompromised patients with cystic fibrosis [37]. They colonize the respiratory system, urinary and gastrointestinal tract, as well as the central nervous system, eyes, ears, skin and bones [38]. Recently, there has been a tendency to increase carbapenem and multidrug AMR. Mechanisms for it include multidrug efflux pumps, $\beta$-lactamases and suppressing porins on the outer cell membrane. The virulent factors include toxin secretion and biofilm formation. Successful treatment of $P$. aeruginosa infections requires appropriate control and timely administration of antibacterial agents, such as the ceftolozan/ tazobactam combination, which is active in low doses even for $\operatorname{ampC~} \beta$-lactamase- and efflux-mediated resistance to other $\beta$-lactam antibiotics [39]. However, not all members of the genus Pseudomonas cause infectious diseases. Some authors showed the resistance of $P$. xanthomarina to a high concentrations of arsenic and have potential to metabolize this element through arsenite oxidation [40].

Members of the genus Aeromonas are responsible for a number of infections in humans and animals, incl. gastroenteritis, wound infections, septicaemia, respiratory infections, etc. as liver abscesses, haemolytic uremic syndrome, corneal ulcers and endophthalmitis. They produce a number of virulence factors, such as aerolysin, proteases, adhesins, invasins, enterotoxins, phospholipase and lipase [41]. It was reported the presence of two Shiga toxin genes (stx1 and stx2) in some clinical isolates [42].

As mentioned above, most bacteria can acquire resistance to various chemical-based preparations used in agriculture. In recent years, there has been increased interest in the use of electrochemically activated water (ECAW) as a disinfectant used in agriculture, dentistry, medicine and the food industry [43]. In our previous study we investigated the possibility for decontamination of digestate obtained in the process of biogas production with ECAW [44]. Our results showed that the ECAW with $\mathrm{pH}=7,6$ and $\mathrm{ORP}=800 \mathrm{mV}$ exhibited strong antimicrobial activity in 1:3 ratio digestate or monoculture/ECAW. The obtained chlorine compounds from the electrolysis of water are highly volatile, therefore we are confident that when water enters into the soil, it will be both harmless to plants and will decontaminate the digestate. 


\section{CONCLUSION}

The paper shows that after preliminary adaptation of the anaerobic microbial community in the bioreactor it is possible to carry out $\mathrm{AD}$ of wheat straw without pre-treatment, obtaining very good results concerning quantity and quality of obtained biogas and the degree of biodegradation of the cellulose. This is especially important for practice because it saves significantly pre-treatment (physical, chemical or biological) costs. The experiments were performed in a pilot biogas plant with a computer control system that can be directly applied in industrial pilot biogas plants.

Microbiological studies of the digestate have shown the persistence of potential pathogenic bacteria in the digestate, such as the species from the genera Pseudomonas, Enterococcus and Aeromonas. In this regard, many experimental approaches are being sought to reduce the number of these bacteria in digestate as a product of the degradation of various organic wastes. Such an approach would be the use of electrochemically activated water, which has shown bactericidal activity in preliminary studies [44]. This, as well as other experimental approaches, would reduce the degree of microbial contamination of the obtained digestate and, accordingly, would reduce the risk of the spread of pathogenic and conditionally pathogenic microorganisms in the environment. Similarly, the issue of the spread of antimicrobial resistance among various microorganisms - inhabitants of the environment. The elimination of pathogenic microflora will lead to the elimination of beneficial microflora, but in the soil will remain useful products of their metabolic activity, which will increase soil quality and yields of various crops.

ACKNOWLEDGMENT: This work was supported by the BNSF Grant KP-06-IP-CHINA/3.

\section{REFERENCES}

1. Ahring, B.K., I. Angelidaki, C.C. de Macario, H. Gavala, J. Hofman-Bang, S.O. Elfering, L. Raskin, A. Stams, P. Westermann, and D. Zheng, Biomethanation I. Vol. 81. 2003: Springer.

2. Angelidaki, I., L. Ellegaard, B.K. Ahring, I.V. Skiadas, H.N. Gavala, J.E. Schmidt, B.K. Ahring, A. Mogensen, J. Dolfing, and F. Haagensen, Biomethanation II. Chap. Applications of the anaerobic digestion process, 2003: p. 1-33.

3. Deublein, D. and A. Steinhauser, Biogas from waste and renewable resources: an introduction. 2011: John Wiley \& Sons.
4. Simeonov, I., S. Mihajlova, D. Galabova, N. Kostadinova, and V. Akivanov, Anaerobic digestion of lignocellulosic wastes in a pilot scale biogas plant (in Bulgarian). Ecological Engineering and Environment Protection, 2019(4): p. 54-65.

5. Simeonov, I., D. Denchev, S. Mihailova, V. Hubenov, and E. Chorukova, Composition for Biogas Production, P.O.o.t.R.o. Bulgaria, Editor. 2013: Bulgaria.

6. Mystkowski, E., Poferment $z$ biogazowni rolniczej nawozem dla rolnictwa. Kukurydza, 2015(1).

7. Koszel, M. and E. Lorencowicz, Agricultural use of biogas digestate as a replacement fertilizers. Agriculture and Agricultural Science Procedia, 2015. 7: p. 119-124.

8. Sahlström, L., E. Bagge, E. Emmoth, A. Holmqvist, M.-L. Danielsson-Tham, and A. Albihn, A laboratory study of survival of selected microorganisms after heat treatment of biowaste used in biogas plants. Bioresource Technology, 2008. 99(16): p. 7859-7865.

9. Zlatareva, E., P. Ivanov, S. Marinova, I. Simeonov, and S. Mihailova, Comparative evaluation of digestate from anaerobic biodegradation with other soil improvers (in Bulgarian). Ecological Engineering and Environment Protection, 2013(3-4): p. 119-123.

10. Gerardi, M.H., The microbiology of anaerobic digesters. 2003: John Wiley \& Sons.

11. Simeonov, I., B. Kalchev, S. Mihaylova, V. Hubenov, A. Aleksandrov, R. Georgiev, and N. Christov, Pilot-scale biogas plant for the research and development of new technologies. International Journal Bioautomation, 2012. 16(3): p. 187.

12. Simeonov, I., E. Chorukova, S. Diop, and N. Christov. Pilot Scale Biogas Reactor with Computer System for Monitoring and Control. in Proc. of Septième édition du Colloque Francophone en Energie, Environement, Economie et Thermodynamique (COFRET'14), Paris, France, April. 2014.

13. Simeonov, I., E. Chorukova, V. Akivanov, V. Lakov, and S. Mihailova, Experimental pilot scale biogas plant with computer system for monitoring and control, in International Conference Automatics and Informatics. 2017, John Atanasoff Society of Automatics and Informatics: Sofia, Bulgaria.

14. EUCAST. Breakpoint tables for interpretation of MICs and zone diameters. Version 11.0. 2021; Available from: http://www.eucast.org. 
15. Kabaivanova, L., I. Simeonov, D. Denchev, S. Mihaylova, V. Hubenov, R. Nikolova, and D. Todorova, Thermochemical pretreatment of lignocellulosic substrates for anaerobic digestion at mesophilic and thermophilic conditions (in Bulgarian). Ecological Engineering and Environment Protection, 2016(2): p. 42-49.

16. Acevedo, M.M., L.M. Carroll, M. Mukherjee, E. Mills, L. Xiaoli, E.G. Dudley, and J. Kovac, Bacillus clarus sp. nov. is a new Bacillus cereus group species isolated from soil. BioRxiv, 2019: p. 508077.

17. Griffiths, M. and H. Schraft, Bacillus cereus food poisoning, in Foodborne diseases. 2017, Elsevier. p. 395-405.

18. Osman, K.M., A.D. Kappell, A. Orabi, K.S. Al-Maary, A.S. Mubarak, T.M. Dawoud, H.A. Hemeg, I.M. Moussa, A.M. Hessain, and H.M. Yousef, Poultry and beef meat as potential seedbeds for antimicrobial resistant enterotoxigenic Bacillus species: a materializing epidemiological and potential severe health hazard. Scientific reports, 2018. 8(1): p. 1-15.

19. Tuazon, C.U., Bacillus species. Last accessed on, 2016.

20. Waewthongrak, W., S. Pisuchpen, and W. Leelasuphakul, Effect of Bacillus subtilis and chitosan applications on green mold (Penicilium digitatum Sacc.) decay in citrus fruit. Postharvest Biology and Technology, 2015. 99: p. 44-49.

21. Leelasuphakul, W., P. Sivanunsakul, and S. Phongpaichit, Purification, characterization and synergistic activity of $\beta-1,3$-glucanase and antibiotic extract from an antagonistic Bacillus subtilis NSRS 89-24 against rice blast and sheath blight. Enzyme and Microbial Technology, 2006. 38(7): p. 990-997.

22. Ongena, M. and P. Jacques, Bacillus lipopeptides: versatile weapons for plant disease biocontrol. Trends in microbiology, 2008. 16(3): p. 115-125.

23. Arrebola, E., D. Sivakumar, and L. Korsten, Effect of volatile compounds produced by Bacillus strains on postharvest decay in citrus. Biological control, 2010. 53(1): p. 122-128.

24. Madhaiyan, M., S. Poonguzhali, S.-W. Kwon, and T.-M. Sa, Bacillus methylotrophicus sp. nov., a methanol-utilizing, plant-growth-promoting bacterium isolated from rice rhizosphere soil. International Journal of Systematic and Evolutionary Microbiology, 2010. 60(10): p. 2490-2495.

25. Tanyildizi, M.S., D. Özer, and M. Elibol, Production of bacterial $\alpha$-amylase by $B$. amyloliquefaciens under solid substrate fermentation. Biochemical engineering journal, 2007. 37(3): p. 294-297.

26. AlGburi, A., A. Volski, C. Cugini, E.M. Walsh, V.A. Chistyakov, M.S. Mazanko, A.B. Bren, L.M. Dicks, and M.L. Chikindas, Safety properties and probiotic potential of Bacillus subtilis KATMIRA1933 and Bacillus amyloliquefaciens B-1895. Advances in Microbiology, 2016. 6(6): p. 432-452.

27. White Jr, J.F., M.S. Torres, R.F. Sullivan, R.E. Jabbour, Q. Chen, M. Tadych, I. Irizarry, M.S. Bergen, D. Havkin- Frenkel, and F.C. Belanger, Occurrence of $B$ acillus amyloliquefaciens as a systemic endophyte of vanilla orchids. Microscopy Research and Technique, 2014. 77(11): p. 874-885.

28. Molnár, A., B. Podmaniczky, P. Kürti, I. Tenk, R. Glávits, G. Virág, and Z. Szabó, Effect of different concentrations of Bacillus subtilis on growth performance, carcase quality, gut microflora and immune response of broiler chickens. British poultry science, 2011. 52(6): p. 658-665.

29. Chistyakov, V., V. Melnikov, M.L. Chikindas, M. Khutsishvili, A. Chagelishvili, A. Bren, N. Kostina, V. Cavera, and V. Elisashvili, Poultry-beneficial solid-state Bacillus amyloliquefaciens B-1895 fermented soybean formulation. Bioscience of microbiota, food and health, 2014.

30. Trivedi, N., V. Gupta, M. Kumar, P. Kumari, C. Reddy, and B. Jha, An alkalihalotolerant cellulase from Bacillus flexus isolated from green seaweed Ulva lactuca. Carbohydrate polymers, 2011. 83(2): p. 891-897.

31. Priyadarshini, S., V. Gopinath, N.M. Priyadharsshini, D. MubarakAli, and P. Velusamy, Synthesis of anisotropic silver nanoparticles using novel strain, Bacillus flexus and its biomedical application. Colloids and Surfaces B: Biointerfaces, 2013. 102: p. 232-237.

32. An, S.-Y., M. Asahara, K. Goto, H. Kasai, and A. Yokota, Terribacillus saccharophilus gen. nov., sp. nov. and Terribacillus halophilus sp. nov., spore-forming bacteria isolated from field soil in Japan. International Journal of Systematic and Evolutionary Microbiology, 2007. 57(1): p. 51-55.

33. Essghaier, B., C. Dhieb, H. Rebib, S. Ayari, A.R.A. Boudabous, and N. Sadfi-Zouaoui, Antimicrobial behavior of intracellular proteins from two moderately halophilic bacteria: strain J31 of Terribacillus halophilus and strain M3-23 of Virgibacillus marismortui. Journal of Plant Pathology \& Microbiology, 2014. 5(1): p. 1. 
34. Maria da Glória, S.C., A.G. Steigerwalt, R.E. Morey, P.L. Shewmaker, E. Falsen, R.R. Facklam, and L.M. Teixeira, Designation of the provisional new Enterococcus species CDC PNS-E2 as Enterococcus sanguinicola sp. nov., isolated from human blood, and identification of a strain previously named Enterococcus CDC PNS-El as Enterococcus italicus Fortina, Ricci, Mora, and Manachini 2004. Journal of clinical microbiology, 2008. 46(10): p. 3473-3476.

35. Shewmaker, P.L., A.G. Steigerwalt, A.C. Nicholson, S.C. Maria da Glória, R.R. Facklam, A.M. Whitney, and L.M. Teixeira, Reevaluation of the taxonomic status of recently described species of Enterococcus: evidence that E. thailandicus is a senior subjective synonym of "E. sanguinicola" and confirmation of E. caccae as a species distinct from E. silesiacus. Journal of clinical microbiology, 2011. 49(7): p. 2676-2679.

36. García-Solache, M. and L.B. Rice, The Enterococcus: a model of adaptability to its environment. Clinical microbiology reviews, 2019. 32(2).

37. Schwarz, C., J.-P. Bouchara, W. Buzina, V. Chrenkova, H. Dmeńska, E.G.G. de la Pedrosa, R. Cantón, E. Fiscarelli, Y. Le Govic, and N. Kondori, Organization of patient management and fungal epidemiology in cystic fibrosis. Mycopathologia, 2018. 183(1): p. 7-19.

38. Baltch, A.L. and R.P. Smith, Pseudomonas aeruginosa: infections and treatment. Pseudomonas aeruginosa: infections and treatment., 1994(12).

\section{Prof. Hristo Najdenski, DVM, DSc \\ Corr. Member of BAS \\ Department of Infectious Microbiology \\ The Stephan Angeloff Institute of Microbiology \\ Acad. G. Bonchev Str., Bl. 26 \\ 1113 Sofia, Bulgaria \\ e-mail: hnajdenski@abv.bg}

\author{
Assist. Prof. Lyudmila Dimitrova, PhD \\ Department of Infectious Microbiology \\ The Stephan Angeloff Institute of Microbiology \\ Acad. G. Bonchev Str., Bl. 26 \\ 1113 Sofia, Bulgaria \\ e-mail: lus22@abv.bg
}

\author{
Assoc. Prof. Veselin Akivanov, PhD \\ John Atanasoff Society of Automatics and \\ Informatics \\ 108 Rakovski Str., \\ Sofia 1000, Bulgaria \\ e-mail: akiwanov@abv.bg
}

39. Soliman, R., S. Lynch, E. Meader, R. Pike, J.F. Turton, R.L. Hill, N. Woodford, and D.M. Livermore, Successful ceftolozane/tazobactam treatment of chronic pulmonary infection with panresistant Pseudomonas aeruginosa. JMM Case Reports, 2015. 2(2): p. e000025.

40. Koechler, S., F. Arsène-Ploetze, C. Brochier-Armanet, F. Goulhen-Chollet, A. HeinrichSalmeron, B. Jost, D. Lièvremont, M. Philipps, F. Plewniak, and P.N. Bertin, Constitutive arsenite oxidase expression detected in arsenic-hypertolerant Pseudomonas xanthomarina S11. Research in microbiology, 2015. 166(3): p. 205-214.

41. Parker, J.L. and J.G. Shaw, Aeromonas spp. clinical microbiology and disease. Journal of Infection, 2011. 62(2): p. 109-118.

42. Alperi, A. and M. Figueras, Human isolates of Aeromonas possess Shiga toxin genes (stxl and stx2) highly similar to the most virulent gene variants of Escherichia coli. Clinical microbiology and infection, 2010. 16(10): p. 1563-1567.

43. Huang, Y.-R., Y.-C. Hung, S.-Y. Hsu, Y.W. Huang, and D.-F. Hwang, Application of electrolyzed water in the food industry. Food control, 2008. 19(4): p. 329-345.

44. Dimitrova, L., V. Kussovski, I. Tsvetkova, V. Hubenov, S. Mihaylova, I. Simeonov, N. Ivanov, G. Gluhchev, and H. Najdenski, Bactericidal effect of electrochemically activated water on the aerobic bacterial population of digestate. Environmental Engineering and Environmental Protection, 2013(4): p. 23-32.

\author{
Assist. Prof. Venelin Hubenov, PhD \\ Department of Biotechnology \\ The Stephan Angeloff Institute of Microbiology \\ Acad. G. Bonchev Str., B1. 26 \\ 1113 Sofia, Bulgaria \\ e-mail: vhubenov@microbio.bas.bg
}

\section{Snejanka Mihailova}

Department of Biotechnology

The Stephan Angeloff Institute of Microbiology

Acad. G. Bonchev Str., B1. 26

1113 Sofia, Bulgaria

e-mail: snejanka11@avb.bg

\section{Assist. Prof. Petar Grozdanov, PhD}

Laboratory Center Pasteur

The Stephan Angeloff Institute of Microbiology

Acad. G. Bonchev Str., B1. 26

1113 Sofia, Bulgaria

e-mail: grozdanov@microbio.bas.bg 
Assoc. Prof. Mihail Iliev, PhD

Faculty of Biology, St. Kliment Ohridski

University of Sofia,

8 Dragan Tsankov Blvd, 1164 Sofia, Bulgaria

e-mail: miliev1@ biofac.uni-sofia.bg

Assoc. Prof. Vesselin Kussovski, PhD

Department of Infectious Microbiology

The Stephan Angeloff Institute of Microbiology

Acad. G. Bonchev Str., Bl. 26

1113 Sofia, Bulgaria

e-mail: vkussovski@gmail.com
Assoc. Prof. Lyudmila Kabaivanova, PhD

The Stephan Angeloff Institute of Microbiology

Acad. G. Bonchev Str., B1. 26

1113 Sofia, Bulgaria

e-mail: 1kabaivanova@yahoo.com

\section{Assoc. Prof. Ivan Simeonov, PhD}

The Stephan Angeloff Institute of Microbiology

Acad. G. Bonchev Str., B1. 26

1113 Sofia, Bulgaria

e-mail: issim@abv.bg 